Chirurgia (2020) 115: 95-101

No. 1, January - February

Copyright $@$ Celsius

http://dx.doi.org/10.21614/chirurgia.115.1.95

\title{
Paracolostomy Evisceration: Short Review and a New Case Report
}

\author{
Ioan Nicolae Mateș ${ }^{1,2^{*}}$, Mircea Gheorghe ${ }^{1,2^{*}}$, Roxana Tomșa ${ }^{3}$, Elena Liliana Sumedrea \\ ${ }^{1}$ Carol Davila University of Medicine and Pharmacy, Bucharest, Romania \\ ${ }^{2}$ Saint Mary Clinic of General and Esophageal Surgery, Bucharest, Romania \\ ${ }^{3} \mathrm{PhD}$ Student, Carol Davila University of Medicine and Pharmacy, Bucharest, Romania \\ ${ }^{4}$ Student, Carol Davila University of Medicine and Pharmacy, Bucharest, Romania
}

Corresponding author: Ioan Nicolae Mateș, PhD, MD Associate Professor, habil Carol Davila University of Medicine and Pharmacy, Bucharest, Romania Saint Mary Clinic of General and Esophageal Surgery

E-mail: ioan.mates@gmail.com

\section{Rezumat}

Evisceratia paracolostomie: scurt review și raportarea unui nou caz

Introducere: Stomiile derivative sunt proceduri comune dar prezintă propria morbiditate (complicații precoce sau tardive). Eviscerația secundară colostomiei este o complicație rară dar potențial letală (necesită chirurgie de urgență), relativ nedocumentată privitor la mecanismul de producere.

Prezentare de caz: Un pacient de 84 ani este internat pentru ocluzie digestivă joasă cronică prin cancer rectal avansat local, stenozant. În vederea radiochimioterapiei neoadjuvante se practică sigmoidostomie pe ansă în continuitate, prin abord iliac stâng, fără pregătirea colonului. Ansa sigmoidiană plină de fecaloame. Breşa parietală recalibrată cu două suturi monoplan nerezorbabile; stoma fixată la fascie şi tegument. Stoma a fost maturată după 2 zile, dar nefuncțională (ileus postoperator). În ziua a $3-a$ se constată eviscerație parastomală liberă prin dehiscența parietorafiei. Reintevenție de urgență prin acelaşi abord.

Rezultate: Evoluție imediată favorabilă. CT toracoabdminal: N0,M0. RMN pelvin: proces proliferativ stenozant pe rect inferior şi mijlociu, cu infiltrarea fasciei mezorectale, ridicătorilor anali şi câteva adenopatii regionale. După radiochimioterapie a fost reoperat (amputație pe cale abdominoperineală). Rezultat patologic: adenocarcinom colorectal G2, regresie tumorală aproape completă, ypT1ypN0, ICD-O: 8140/3.

Concluzii: Am analizat 8 prezentări de caz publicate începând cu 2011, cu distribuție egală privind intervalul apariției eviscerației (tardivă sau precoce). Nu am constat legătură cu indicația inter- 
venției inițiale (cancer colorectal doar la jumătate din cazuri), nici cu topografia (transvers sau sigmoid) sau tipul colostomiei (terminală sau în continuitate). Apariția complicației nu depinde de intervalul față de operația inițială (5-18 luni pentru cele tardive, 3-12 zile pentru eviscerațiile precoce). Principala premiză este colostomia în sine (un loc de rezistență parietală redusă), solicitată de creşterea presiunii intra-abdominale (ex: tuşitori cronici, ocluzie intestinală). Factorii predispozanți în cazul eviscerației tardive par să fie legați de ruptura spontană a eventrației parastomale/prolapsului. Pentru eviscerațiile precoce trebuie luate în calcul deficiențe de tehnică şi strategie chirurgicală (fixare insuficientă; crearea unei colostomii cu diametru inutil de mare).

Cuvinte cheie: colostomie, eviscerație parastomală, chirurgie colorectală, chirurgie de urgență

\section{Abstract}

Introduction: Diverting ostomy is a commonly perfomed procedure but may be associated to its own morbidity (early or late complications). Colostomy-related evisceration is a rare but potentially life threatening condition (requiring emergency surgery), relatively undocumented for its mechanisms. Case report: A male aged 84 was admited for chronic low digestive occlusion due to a locally advanced, stenosing, rectal adenocarcinoma. Prior to neoadjuvant therapy, a loop sigmoidostomy was indicated using a left iliac open aproach, with no preparation of the colic content. The sigmoid was loaded with hard stools. The parietal breach was reaproximated by 2 monofilament nylon sutures, fascial and colocutaneus fixation. Colostomy was opened two days later, but was not functional (postoperative paralytic ileus). Parastomal evisceration of ileum in day 3 , dehiscence of parietal suture. Emergency operation, using the same aproach.

Results: Favourable outcome. Thoraco-abdominal CT scan: N0,M0. Pelvic MRI: proliferative mass of inferior and middle rectum, involving mesorectum fascia, levator ani and a few regional lymphatic nodes. Radio-chemotherapy and abdomino-perineal resection. Pathologic result: colorectal adenocarcinoma, G2, ypT1ypN0, ICD-O: 8140/3.

Conclusions: We rewiewed 8 case reports published since 2011, equally distributed as late or early complications. There was no connection with the princeps indication (colorectal cancer in half of cases); neither related to topography (transverse or sigmoid) or type of colostomy (loop or end). Occurence of the complication is not time-dependent (5 to18 months in late, 3 to 12 days for early eviscerations). The main premise is colostomy itself (a place of reduced parieto-abdominal resistence), stressed by increassed intra-abdominal pressure (eg. bronchopulmonary disease, digestive obstruction). Predisposing factors for late evisceration seems to be related to spontaneous rupture of parastomal hernia/colostomy prolapse. As for early evisceration, both technical details and surgical strategy must be considered (indequate fixation; creation of a larger than necessary colostomy aperture).

Key words: colostomy, parastomal evisceration, colorectal surgery, emergency surgery

\section{Introduction}

Diverting ostomy (temporary/permanent) is a commonly performed procedure in emergency/ elective digestive surgery, usually involving the terminal ileum or distal colon. There is a large range of its indications, although the first one is colorectal cancer; there are also various available techniques, such as end- or loop ostomy, in open/minimally invasive surgery.

Ostomy is associated to its own morbidity, 
even mortality, with a variable incidence of early or late complications. Some consider that "temporary stomal complications are low, due to most of the pacients undergo early stoma revearsal" (1); but this is not always true, since morbidity may be recorded in the period between stoma construction and scheduled closure (2-7). Futhermore, in a study (8) on 2528 consecutive patients with rectal cancer (low anterior resection with temporary stoma), only $93,9 \%$ had the chance of stoma reversal (median period between primary surgery and stoma reversal: 7.5 months) and the risk for permanent stoma was related to "local recurrence and anastomotic-related complications". The rate of complications tends to rise over time for permanent stomas, influencing the quality of life - QOL (9-11).

Malik TAM et al. (12) published a systematic review on 18 trials involving 1.009 adult patients; the incidence of stoma related complications ranged from $2,9 \%$ to $81,1 \%$. The usual indications for ostomy were: "colorectal cancer, diverticular disease and inflammatory bowell disease"; other presenting conditions included: "faecal incontinence, constipation, irritable bowel syndrome, typhoid, tuberculosis, trauma, colovesical fistula and familial adenomatous polyposis syndrome". The most common stoma related complications were: peristomal skin complications and parastomal hernia. Complications were classified as early (within one month of surgery, such as: "high output stoma, peristomal irritation, stoma infection, ischaemia and retraction") or late ("parastomal hernia, stoma prolapse and stenosis").

\section{Case Report}

A 84-year old caucasian male was admited in april 2019 for a 2-month history of late stools emission (constipation, moderate abdominal distension) and rectal tenesmus, as well as years-long dysuria. Previous colonoscopy demonstrated presence of 3 colonic low-grade tubular adenomas and rectal stenosis (circumferential, ulcerovegetant tumor, extending from aprox. 3 to $8 \mathrm{~cm}^{-}$conventional rectal adenocarcinoma).
Per rectal examination revealed a tight tumoral low rectal stenosis $(\sim 15 \mathrm{~mm})$ - chronic low occlusion; also an enlarged prostate. Low serum iron $(41 \mathrm{mcg} / \mathrm{dl})$; free PSA $1.15 \mathrm{ng} / \mathrm{ml}$, PSA $3.84 \mathrm{ng} / \mathrm{ml}$. Prostate ultrasonography: PV- $80 \mathrm{cc} / \mathrm{mL}, 70 / 40 / 65 \mathrm{~mm}$. Urologist's opinion: prostate adenoma (BPH), with associated prostatitis.

It was considered that the locally-advanced rectal cancer must be submited to neoadjuvant therapy, preclued by colic bypass to avoid acute low-level bowel obstruction. Loop sigmoidostomy on a stoma rod (without previous preparation of the colic content) in open surgery: an oblique incision in the left inferior abdominal quadrant, involving the rectus abdominis. Exteriorisation of the sigmoid loop (with hard stool); the parietal breach was fashioned and reaproximated by 2 nonabsorbable monofilament (nylon) sutures, followed by fascial and colocutaneus fixation. Colostomy was opened (maturated) two days later, but was not functional (postoperative paralytic ileus). Parastomal evisceration of bowell loops in day 3 (Fig. 1), dehiscence of parietal suture. Immediate emergency operation (within 2 hours), using the same surgical aproach; reduction of viable eviscerated ileum, refashioning of the fascial closure. Thoracic and abdominal CT scan: N0, M0. Pelvic MRI (Fig. 2, 3): circumferential stenosing proliferative process, involving the inferior and middle

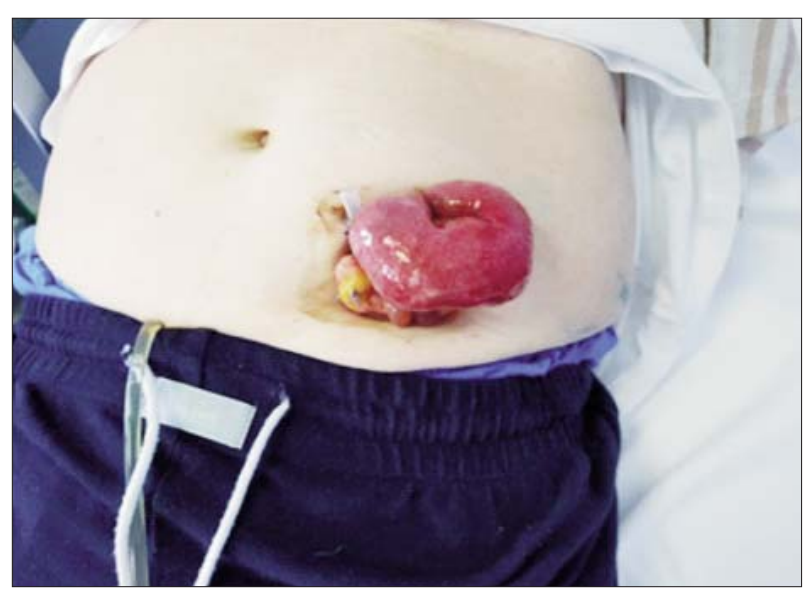

Figure 1. Free evisceration of small bowel, alongside loop sigmoidostomy. 


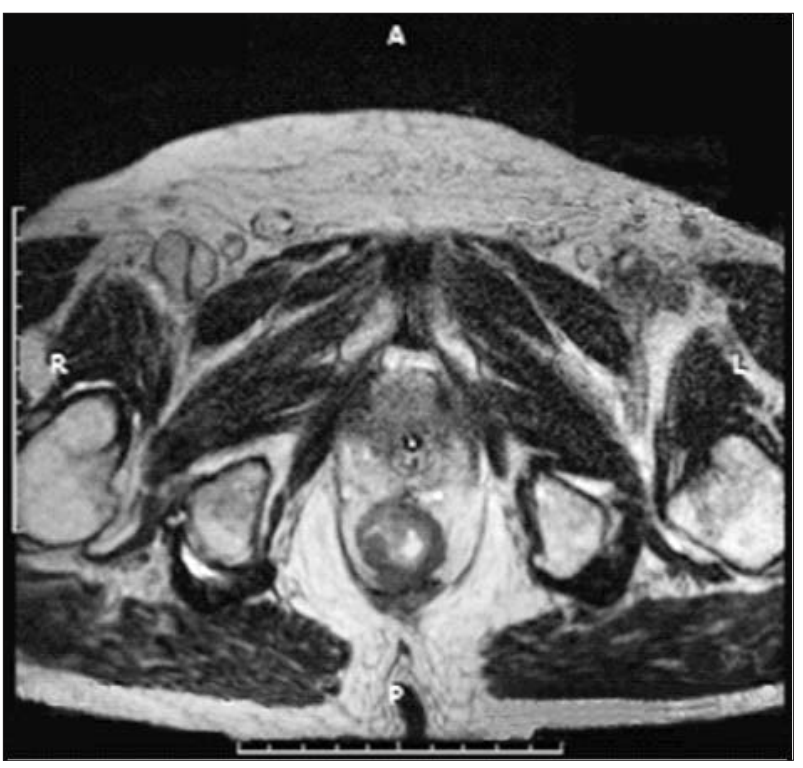

Figure 2. Pelvic MRI (contrast; transverse section).

rectum, mesorectum fascia and levator ani, a few regional lymphatic nodes $(>8 \mathrm{~mm})$; suspected prostate atypia $(64 / 53 / 61 \mathrm{~mm}$, disruption of prostate capsula, no interface to seminal glands). Favourable surgical outcome; oncological and urological survey.

Pacient folowed radiochemotherapy (28 sessions, june-july 2019) and was readmitted in octombre 2019 for completion of surgical treatment; functional stoma, large parastomal hernia. He was reevaluated (a new pelvic MRI) and reoperated, also in open surgery: abdomino-perineal resection, conversion of loop- to end colostomy, cure of parastomal hernia. Pathologic result: colorectal adenocarcinoma (ICD-O: 8140/3), G2, with almost complete regression (modiffied Ryan 2); stage ypT1ypN0. No need for adjuvant therapy.

\section{Discussion}

Stoma-related evisceration (parastomal evisceration, a potential life threatening condition) is an uncommon and low frequency event, reported only by a very few case-reports so far; not included in randomised controlled trials. It is relatively undocumented, specialy for its mechanisms and predisposing factors. Immediate surgery is always necessary for:

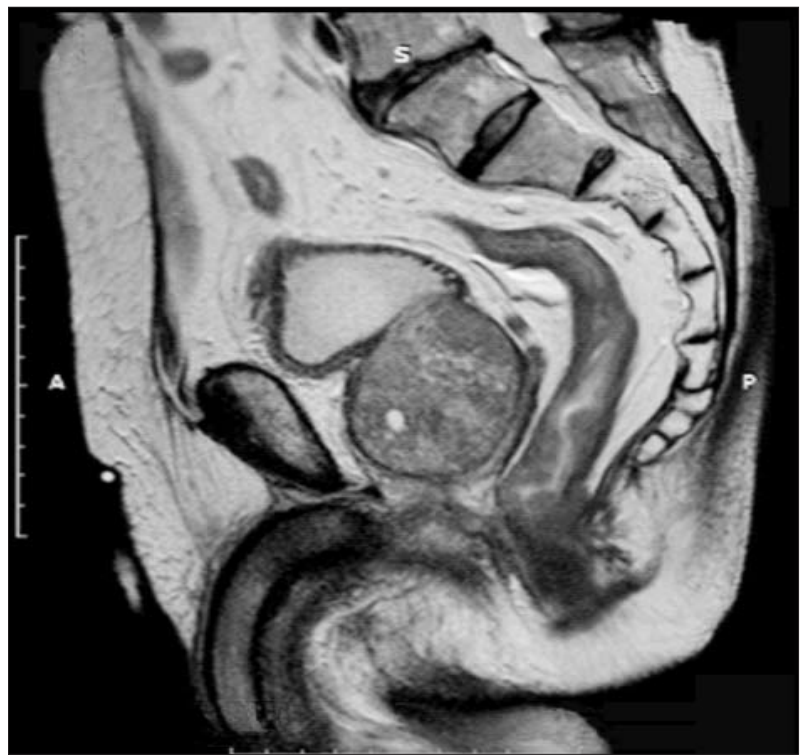

Figure 3. Pelvic MRI (contrast; longitudinal section).

reduction of the eviscerated mass (or small bowell/ colic resection, if nonviable), refashioning of the stoma (or creation of a new stoma) and adequate fascia closure.

Kulkarni AA et al. (4) published a review on 10 previously reported cases of parastomal evisceration (5 ileostomy and 5 colostomy cases; including both early and late evisceration) and a report of another two colostomy cases in the early postoperative period. Herein we reported a new case of early parastomal evisceration, secondary to colostomy. For the purpose of our study we excluded ileostomy-related parastomal eviscerations and focused on conditions related to colostomy evisceration. We reviewed four articles concerning 4 case reports of late evisceration $(1,3,5,13)$ and three articles on 4 case reports $(4,6,7)$ presenting early postoperative para-stomal evisceration after colostomy (within one month after creation of the colostomy). All case reports were published since 2011. There were 7 males (aged 45-69, median: 58) and 1 female (aged 50); age and gender were disregarded. We review on the following: indication of the princeps (index) operation; topography and type of colostomy; interval after colostomy; causative and predisposing conditions, related to late or early colostomy evisceration, and other aspects. 


\section{Late Eevisceration}

The most frequent indication for colostomy was rectal cancer $(1,3,13)$; the indication for colostomy was extensive hidradenitis suppurativa of the perineum in another case-report (5). Evisceration occured within a time span of 5 (5) to 18 months (13). Anatomical site and fashion of colostomy were irelevant, since the complication was associated to: transverse loop (3) or end (13) colostomy, as well as to loop sigmoid colostomy (5) or end descending colostomy (1). Partial resection (because definitive ischemia and necrosis) was needed in only one case report (12): right hemicolectomy, partial necrosis of previous transverse end colostomy. No fatality was reported.

Late evisceration of small bowel loops is described as a consequence of stress on colostomy site (an aquired defect, a point of minimal parietal resistence), exerted by increased intra-abdominal pressure. In the case report published by Villa $\mathrm{M}$ et al. (3) increased intra-abdominal pressure was secondary to an acute intestinal obstruction (jejunal loops strangulated by an omentum band). In three studies increased intraabdominal pressure was atributed to episodes of chronic/sustained cough in patients with previous chronic obstructive pulmonary diseaseCOPD $(1,5)$ or severe pulmonary fibrosis following chemotherapy, treated with high dose cortisone (12).

The predisposing condition was an underlying (previous) parastomal hernia with/ without colostomy prolapse, followed by spontaneous rupture due to necrosis. Evisceration can not be atributed to colostomy itself, but to its secondary complications (parastomal hernia, prolapse); some consider that "such pacients may need early refashioning of the stoma to prevent this serious complication" (5).

\section{Early Evisceration}

In a multivariate analysis by Duchene JC at al. (14) on 164 ostomy patients (colo- and ileostomy), 39\% presented early complications (within one month of the procedure) that were not associated to the location/type of ostomy; no case of early evisceration was included in this study.

We review on 4 case reports in three studies $(4,6,7)$. The indication for colostomy consisted in: iatrogenic rectal injury during surgery for sacral chordoma, or rectovaginal fistula secondary to locally advanced carcinoma cervix (4); rectal adenocarcinoma with obstructive acute abdomen (6) and severe necrotizing perianal fasciiitis (7). Colorectal cancer was the princeps indication of colostomy in only 1 case out of 4 ; in 2 cases a benign pathology was involved and in 3 situations the colostomy was intended to be temporary, not permanent. Topography and type of colostomy were difficult to corelate to complication's early occurence: loop transverse ostomy (6), end sigmoid colostomy (7) or loop sigmoid colostomy (4). Resection was necessary in two case reports $(6,7)$; one reported fatality (4)- sepsis with multiorgan dysfunction; contamination with feces of the protruding small bowell loops through the colostomy site. In all four case reports the colostomy was maturated (opened) and functional before the occurence of early evisceration.

Kulkarny AA et al. (4) stated that "in the majority of reported cases, evisceration was reported within a few days after the index surgery". This is also true in our review on early evisceration following colostomy (day 3 to 12 ; median: 4 days).

Early evisceration at the site of colostomy seems to be ralated both to pathological condition of the patient, as well as surgical therapy (strategy and technical details). Increased intra-abdominal pressure was blaimed in case reports by: Salles VJA et al. (6)- COPD, bronchospasm crisis with intermmitent cough requiring mechanical ventilation; Azouz V et al. (7)- COPD; Kulkarni AA et al. (4) - severe bout of coughing.

Surgical failure related to technical details (such as colostomy diameter, fascia fixation, aponeurotic closure, colocutaneous sutures) were considered a possible cause of early evisceration; especially a disproportionate large colostomy orifice. Azouz V et al (7) 
believe that, in their case report, the cause of parastomal fascial dehiscence was a "stomatal aperture that is just a centimeter larger than the accepted ideal size"; the fascial defect was "dilated to three fingers widths", but "sutures were placed at the level of the skin and not placed at the level of the fascia". Salles VJA et al (6) thought that one of the triggering factors associated to evisceration was technical failure: "the whole diameter of stoma was larger than required for colon extrusion, due to the large transverse colon distension observed in the episode of acute intestinal obstruction". Kulkarni AA et al (4) also blamed a larger stomal apperture to accomodate dilated bowell in one case-report (loop sigmoidostomy): "the sigmoid colon was grossly distended and loaded with hard stool".

Our case-report is similar to previos reported early eviscerations, secondary to an open surgery loop sigmoidostomy performed for an (almost) complet rectal stenosis determined by a circumferential, locally advanced, rectal adenocarcinoma. Rectal cancer was associated to chronic low occlusion; preparation of colic content was avoided to prevent an acute low-bowell obstruction, so the sigmoid was filled by hard stools. Evisceration of ileal loops (with disruption of fascia sutures) was recorded in day 3 , not neccesary related to technical details but to surgical strategy. Maybe, instant maturation of the stoma could avoid the conflict between an increased intraabdominal pressure (previous chronic low occlusion; postoperative adynamic/paralytic ileus, non functional colostoma) and the relative size of the stoma created to accomodate the viscus. Both immediate and late outcome were favourable.

\section{Conclusions}

Diverting ostomy (ileo/colostomy) is a common surgical procedure (as end/loop ostomy; in open/minimally invasive surgery), with century-long history in digestive surgery. Its utility is already demonstrated, in emergency lelective surgery, for various pathologies (mainly colorectal cancer). It is associated to its specific morbidity. Common complications of ostomy are frequent, but not emergencies. On the contrary, parastomal evisceration is a rare and potential life threatening condition, allways in need of emergency surgery.

Colostoma-related evisceration was reported in only a few case reports, published since 2011. The review concerns 8 case reports, equally distributed as late or early evisceration. Despite low frequency, it may be associated to high morbidity; even in temporary stomas. Colorectal cancer was the index indication of colostomy in only half of reported cases, so it is difficult to be considered a predisposing factor. Topography- anatomical site (3 transverse vs 5 descendent/sigmoid colon) and type of colostomy (5 loop vs 3 end) were also irrelevant. It must be kept in mind that stomal aperture is allways larger in loop- comparative to end colostomy, for exteriorising a double loop instead of a single one. Evisceration may complicate colostomy both in the late (5-18 months; median 11) or early (3-12 days; median 4) interval after surgery, so it is not timedependent. Undelying (causative) mechanisms and predisposing factors are still ill-defined; late and early evisceration may share some premises and also present specific aspects.

The main premise of evisceration is colostomy itself, a place of reduced parieto-abdominal resistence and stressed by increassed intraabdominal pressure, related to previous chronic pathological conditions of the patient (episodes of cough or bronchospasm, bronchopulmonary disease); seldom to actual conditions (digestive obstruction). The triggering factors for late evisceration seems to be related to spontaneous rupture (necrosis) of parastomal hernial colostomy prolapse (secondary complications of colostomy). As for early evisceration, both technical details and surgical strategy must be considered; our case report is similar to other previosly reported.

\section{Author's Contributions}

*These authors contributed equally to this work. 


\section{Conflict of interest}

None declared.

\section{References}

1. Yucel AF, Pergel A, Aydin I, Sahin DA. A rare stoma-related complication: parastomal evisceration. Indian J Surg. 2014;76(2):154-5.

2. Gooszen AW, Geelkerken RH, Hermans J, Lagaay MB, Gooszen HG. Temporary decompression after colorectal surgery: randomized comparison of loop ileostomy and loop colostomy. Br J Surg. 1998; 85(1):76-9.

3. Villa M, lannelli E, Grande M, Rossi P, Tucci G. An unusual case of small intestine evisceration through a transverse loop colostomy. Colorectal Dis. 2012;14(1):e27-8.

4. Kulkarni AA, Chauhan V, Sharma V, Singh H. Parastomal evisceration: a report of two cases and review of literature. Cureus. 2019; 11(9):e5750.

5. Basnayake 0, Jayarajah U, Jayasinghe J, Wijerathne PK, Samarasekera DN. Spontaneous rupture of a parastomal hernia with evisceration of small bowel: a case report. BMC Surg. 2019; 19(1):43.

6. Salles VJA, Saba E, Pissinin ER, Arguello ERF, Filho HNM. Complication related to colostomy orifice: intestinal evisceration. J Coloproctol. 2011;31(4):397-400.
7. Azouz V, Simmons JD, Abourjaily GS. Immediate postoperative parastomal end sigmoid hernia resulting in evisceration and strangulation. J Surg Case Rep. 2014;2014(5).

8. Lee CM, Huh JW, Park YA, Cho YB, Kim HC, Yun SH, et all. Risk factors of permanent stomas in patients with rectal cancer after low anterior resection with temporary stomas. Yonsei Med J. 2015; 56(2):447-53.

9. Anaraki F, Vafaie M, Behboo R, Maghsoodi N, Esmaeilpour S, Safaee A. Quality of life outcomes in patients living with stoma. Indian J Palliat Care. 2012; 18(3):176-80.

10. Vonk-Klaassen SM, de Vocht HM, den Ouden ME, Eddes EH, Schuurmans MJ. Ostomy-related problems and their impact on quality of life of colorectal cancer ostomates: a systematic review. Qual Life Res. 2016; 25(1):125-33.

11. Jayarajah U, Samarasekera DN. A cross-sectional study of quality of life in a cohort of enteral ostomy patients presenting to a tertiary care hospital in a developing country in South Asia. BMC Res Notes. 2017;10(1):75.

12. Malik T, Lee MJ, Harikrishnan AB. The incidence of stoma related morbidity - a systematic review of randomised controlled trials. Ann R Coll Surg Engl. 2018;100(7):501-508.

13. Lolis ED, Savvidou P, Vardas K, Loutseti D, Koutsoumpas V. Parastomal evisceration as an extremely rare complication of a common procedure. Ann R Coll Surg Engl. 2015; 97(7).

14. Duchesne JC, Wang YZ, Weintraub SL, Boyle M, Hunt JP. Stoma complications: a multivariate analysis. Am Surg. 2002; 68(11):9616; discussion 966. 